\title{
THE EFFECT OF DIACAMPH HYDROCHLORIDE ON THE CORTISOL CONTENT IN THE BLOOD OF RATS WITH DIABETES MELLITUS MODELLED AGAINST THE IMMOBILIZATION STRESS BACKGROUND
}

\author{
R.D.Zakrutnyi, S.Yu.Shtrygol', S.I.Merzlikin
}

\author{
National University of Pharmacy \\ Key words: diacamph hydrochloride; cortisol; diabetes mellitus; chronic immobilization stress
}

\begin{abstract}
The aim of our study was to determine the effect of diacamph hydrochloride, an original antihyperglycemic drug, on the cortisol content in the blood of animals with a combined model of diabetes mellitus and chronic stress. The experiment was performed on mature male rats. Diabetes mellitus of the 1-st type was modelled by a single injection of alloxan monohydrate (150 mg/kg subcutaneously) and chronic immobilization stress was induced by putting the animals into tight boxes for 16 hours daily over 15 days period beginning from the 11-th day after alloxan injection. It has been found that the concentration of cortisol in the blood plasma of animals of the control pathology group increased essentially as compared to the intact control group. The concentration increased from $77.51 \mathrm{ng} / \mathrm{mol}$ to $421.65 \mathrm{ng} / \mathrm{mol}$, i.e. became 5.4 times higher $(p<0.001)$. It indicates intensity of corticosteroid-mediated mechanisms of stress-response behaviour against the background of modelled diabetes mellitus. Taking contrainsular properties of corticosteroids into account such effect of prolonged immobilization against the background of diabetes mellitus should be considered to be particularly unfavourable. Diacamph hydrochloride (intraperitoneal injections of $25 \mathrm{mg} / \mathrm{kg}$ daily) not only reduced glycemia, but also was likely to decrease the blood cortisol content to $172.0 \mathrm{ng} / \mathrm{ml}$ on the average as compared to the value in the control pathology group ( $p$ <.001). Bemithyl, a classical actoprotector, used as a reference drug (intraperitoneal injections of $50 \mathrm{mg} / \mathrm{kg}$ daily) was found to be statistically significantly inferior to diacamph hydrochloride $(p<0.001)$ as it decreased the cortisol concentration only to $253.35 \mathrm{ng} / \mathrm{ml}$ on the average. The results testify stress-protective properties of diacamph hydrochloride under diabetes mellitus conditions and substantiate the prospects of its further studying as a potential adaptogenic and stress-protective drug. The mechanism of diacamph hydrochloride action is associated with its effect on endocrinous mechanisms of stress reaction.
\end{abstract}

0 ften psychological problems and mental disorders occur in patients suffering from diabetes mellitus (DM). Performance impairment, rapid fatigability, decreased resistance to stress factors can be observed; it has a significant impact on the quality of life $[2,5,7,8]$ and requires effective correction. It has been found in the previous studies that benzimidazole derivative of diacamhp hydrochloride $(\mathrm{DH})$ possessing the antihyperglycemic properties has a powerful actoprotective effect by increasing physical endurance with normoglycemia without affecting the sugar blood level, especially in the DM model, when the increase of physical endurance is followed by normalization of glycemia [3]. These pharmacological properties show the presence of the adaptogenic activity in DH. The question of mechanisms for the DH po- sitive effect on the body's adaptive capacity remains still unclear. It is well known that one of the important elements of adaptiogenesis and the stress reaction course is provided by corticosteroids [1]. Therefore, the aim of this work is to determine the DH effect on the cortisol content in the animal blood with the DM model on the background of the chronic stress.

\section{Materials and Methods}

Tests were carried out in white non-pedigree male rats with the initial weight of $160-180 \mathrm{~g}$. The choice of the animal's gender is conditioned by the fact that the impact of cyclical fluctuations of the endocrine profile in male animals is largely leveled off.

All rats were randomized into 4 groups of 7 animals each. Group 1 consisted of intact normoglycemic rats. Animals of group 2 (control pathology) were modelled the alloxan DH; for this purpose animals were given a single subcutaneous injection of alloxan monohydrate (Sigma, USA) after 24-hour food deprivation, in the dose of $150 \mathrm{mg} / \mathrm{kg}$ as $5 \%$ solution in acetate buffer, pH 4.5 [6]. Before the $\mathrm{DH}$ model test and in 11 days the control of the sugar blood level from the tip of the tail was carried out (glucose oxidase test). Glycemia should exceed $11 \mathrm{mmol} / \mathrm{L}$, which confirms the development of the model DM [6]. Then this group of animals was subjected to the effect of chronic immobilization stress (CIS) for 15 days [1]. Animals of this group were injected with $0.9 \% \mathrm{NaCl}$ solution in the dose of $0.5 \mathrm{mg} / \mathrm{kg}$ intraperitoneally (i.p.).

Group 3 consisted of rats with the DM and CIS model; they were injected DH once a day in a conditionally effective dose of $25 \mathrm{mg} / \mathrm{kg}$ i.p. [3]. Group 4 comprised animals on the background of DM and CIS; they were injected a referen- 
On the background of DH a sig-

Table nificant decrease (by 2.5, $\mathrm{p}<0.001$ ) of the concentration of the tested hormone in the blood took place.

The effect of diacamhp hydrochloride and bemithylum on the cortisol content in the rats' blood with the diabetes mellitus model on the background of the immobilization stress $(n=7)$

\begin{tabular}{|l|c|}
\hline \multicolumn{1}{|c|}{ Animal groups } & Blood cortisol concentration, $\mathrm{ng} / \mathrm{ml}$ \\
\hline Intact control & $77.51 \pm 3.36$ \\
\hline $\begin{array}{l}\mathrm{DM} \text { and } \mathrm{ClS}, 0.9 \% \mathrm{NaCl} \text { solution } \\
\text { (control pathology) }\end{array}$ & $421.65 \pm 11.0^{*}$ \\
\hline $\begin{array}{l}\mathrm{DM} \text { and } \mathrm{ClS} \text {, diacamhp } \\
\text { hydrochloride }(25 \mathrm{mg} / \mathrm{kg} \text { i.p.) }\end{array}$ & $172.00 \pm 6.54^{* *}$ \\
\hline $\begin{array}{l}\mathrm{DM} \text { and } \mathrm{ClS}, \text { bemithylum } \\
(50 \mathrm{mg} / \mathrm{kg} \text { ip) }\end{array}$ & $253.35 \pm 6.93^{* * \wedge}$ \\
\hline
\end{tabular}

Notes:

1) DM - diabetes mellitus, CIS - chronic immobilization stress, i.p. - intraperitoneally;

$2)^{*}$ - statistically significant difference with the intact control $(p<0.001)$;

$3)^{\#}$ - statistically significant difference with the control pathology $(p<0.001)$;

4) $\wedge$ - statistically significant difference with the value on the background of

diacamhp hydrochloride $(p<0.001)$.

ce drug, the well known actoprotector bemithylum in the dose of $50 \mathrm{mg} / \mathrm{kg}$ i.p. [4].

Rats were decapitated immediately after removal from the cases on the 15th day of immobilization and the cortisol content in blood plasma was determined by the immunoenzyme method using standard set CORTISOL KIT (Germany) on Hipson equipment (Czech Republic). The results were subjected to statistical analysis using Student's t-test.

\section{Results and Discussion}

DH unlike bemithylum reduced hyperglycemia already on the first day of application. Thus, if in the control pathology group the sugar blood level on the 11th day of DM modelling was $11.71 \pm 0.01$ $\mathrm{mmol} / \mathrm{L}$ against $6.72 \pm 0.07 \mathrm{mmol} / \mathrm{L}$ in the initial state $(p<0.001)$, and in the bemithylum group - $11.80 \pm$ $\pm 0.07 \mathrm{mmol} / \mathrm{L}$ against $6.67 \pm$ $\pm 0.03 \mathrm{mmol} / \mathrm{L}(\mathrm{p}<0.001)$, then va- lues in the DH group after the first injection were $9.15 \pm 0.07 \mathrm{mmol} / \mathrm{L}$ $(p<0.05$ in relation to the values of the control pathology and bemithylum groups) against $6.60 \pm$ $\pm 0.06 \mathrm{mmol} / \mathrm{L}$. These data confirm the presence of antihyperglycemic properties in $\mathrm{DH}$.

The results of the cortisol content determination in blood plasma are given in Table.

According to the table data, a significant increase of the cortisol content in blood plasma is observed under conditions of the combined DM and CIS model (by 5.4 times compared to the intact control, $\mathrm{p}<0.001$ ). This testifies of the strain of the stress reaction course mechanisms dependent from glucocorticoids. Taken into account the fact that corticosteroids have contrinsular (diabetogenic) properties the effect of prolonged immobilization should be considered especially unfavourable for DM.
Such impact shows not only the stress protective properties of $\mathrm{DH}$, but it can also take part in antidiabetic effect mechanisms, and it requires further study.

Bemithylum produced the similar in direction, but much weaker effect reducing the increased cortisol level by 1.7 times $(\mathrm{p}<0.001$ in relation to the control pathology). These results comply with the well known stress protective properties of this drug [1]. The hormone content exceeded the output level by 3.3 times. However, bemithylum was inferior to $\mathrm{DH}$ $(p<0.001)$ in ability to counteract the increase of the cortisol content in the blood under the conditions of CIS.

Thus, the results show the presence of the stress protective properties in DH under the conditions of DM on the basis of reduction of the increased cortisol content in the blood and substantiate the prospects of further study of this drug as a potential adaptogene and stress protector.

\section{CONCLUSIONS}

1. The cortisol content significantly increases in animals with the alloxan diabetes mellitus model on the background of chronic immobilization stress, and it testifies of the strain of glucocorticoids-dependent mechanisms of the stress reaction.

2. Diacamhp hydrochloride $(25 \mathrm{mg} / \mathrm{kg})$ reduces significantly the cortisol content in the blood probably exceeding bemithylum (50 mg/kg). Thus, the stress protective properties of the drug studied reveal.

\section{REFERENCES}

1. Киричек Л.Т. Стресспротекторы в эксперименте и в клинике. - Х.: ИПП «Конттраст», 2008. - 304 c.

2. Паньків В.И. // Новости медицины и фармации. - 2011. - №383. - С. 22-24.

3. Пат. на корисну модель 70732 Україна, МПК (2012.01) С 07 D 235/16 (2006.01), А 61 К 31/4184 (2006.01), А 61 P 9/00 (士)-Цис-3-(2'-бензімід-азоліл)-1,2,2-триметил-циклопентанкарбонової кислоти гідрохлорид, який виявляє актопротекторну дію / С.І.Мерзлікін, Р.Д.Закрутний, С.Ю.Штриголь, С.М.Коваленко. Заявник та патентовласник: Національний фармацевтичний університет. - №u2011 13990. Заявл.: 28.11.2011. Опубл.: 25.06.2012. - Бюл. №12. - 4 с. 
4. Питкевич Э.С., Лозинский М.О., Лызиков А.Н. и др. Бемитил (bemitylum) - антигипоксант, актопротектор: фармакологические эффекты и клиническое применение в медицине: Информ. бюл. - К., 2001. -44 c.

5. Chyun D.A., Meikus G.D., Katten D.M. et al. // Bio. Rest. Nurs. - 2008. - Vol. 7. - P. 279-288.

6. Dave K.R., Katyare S.S. // J. of Endocrinol. - 2002. - Vol. 175, №1. - P. 241-250.

7. Jacobson A.M., de Groot M., Samson J.A. // Diabetes Care. - 1994. - Vol. 17, №4. - P. 267-274.

8. Imanyama I., Plotnikoff R., Corneya K. et al. // Health and Quality of Life Outcomes. - 2011. - Vol. 9. - P. 115.

9. Wilfley D., Berkowitz R., Goebel-Fabbri A. et al. // Diabetes Care. - 2011. - Vol. 34. - P. 858-860.

\title{
ВПЛИВ ДІАКАМФУ ГІДРОХЛОРИДУ НА ВМІСТ КОРТИЗОЛУ В КРОВІ ЩУРІВ ІЗ МОДЕЛЛЮ ЦУКРОВОГО ДІАБЕТУ НА ТЛІ ІММОБІЛІЗАЦІЙНОГО СТРЕСУ
}

Р.Д.Закрутний, С.Ю.Штриголь, С.І.Мерзлікін

Національний фармацевтичний університет

Ключові слова: діакамфу гідрохлорид; кортизол; иукровий діабет; хронічний іммобілізаційний стрес

Мета дослідження полягала у визначенні впливу оригінального антигіперглікемічного препарату діакамфу гідрохлориду на вміст кортизолу в крові тварин із комбінованою моделлю иукрового діабету та хронічного стресу. Експеримент виконано на дорослих шурах самцях. Цукровий діабет I типу моделювали алоксану моногідратом (150 мг/кг підшкірно одноразово), хронічний іммобілізаційний стрес - розміщенням тварин у тісних пеналах на 16 год щодня протягом 15 діб, починаючи з 11 дня після введення алоксану. Встановлено, що концентрація кортизолу в плазмі крові тварин групи контрольної патології значно зростає відносно інтактного контролю - у середньому з 77,51 нг/мл до 421,65 нг/мл, тобто у 5,4 рази (р<0,001). Це свідчить про напруженість зумовлених кортикостероїдами механізмів перебігу стрес-реакцій на тлі модельного иукрового діабету. З урахуванням контрінсулярних властивостей кортикостероїдів такий ефект тривалої іммобілізації на тлі иукрового діабету слід вважати особливо несприятливим. Діакамфу гідрохлорид (25 мг/кг внутрішньоочеревинно щоденно) не тільки зменшував глікемію, але й вірогідно знижував вміст кортизолу в крові в середньому до 172,0 нг/мл ( $p<0,001$ відносно показника групи контрольної патології). Препарат порівняння класичний актопротектор бемітил (50 мг/кг внутрішньоочеревинно щоденно) статистично значуще поступався діакамфу гідрохлориду (p<0,001), зменшуючи концентрацію кортизолу в середньому лише до 253,35 нг/мл. Результати свідчать про стреспротекторні властивості діакамфу гідрохлориду в умовах иукрового діабету та обгрунтовують перспективність його подальшого вивчення як потенційного адаптогенного та стреспротекторного засобу. Механізм дії діакамфу гідрохлориду пов'язаний із його впливом на ендокринні механізми стрес-реакції.

\section{ВЛИЯНИЕ ДИАКАМФА ГИДРОХЛОРИДА НА СОДЕРЖАНИЕ КОРТИЗОЛА В КРОВИ КРЫС С МОДЕЛЬЮ САХАРНОГО ДИАБЕТА НА ФОНЕ ИММОБИЛИЗАЦИОННОГО СТРЕССА}

Р.Д.Закрутный, С.Ю.Штрыголь, С.И.Мерзликин

Национальный фармацевтический университет

Ключевые слова: диакамфа гидрохлорид; кортизол; сахарный диабет; хронический иммобилизационный стресс

\begin{abstract}
Цель исследования заключалась в определении влияния оригинального антигипергликемического препарата диакамфа гидрохлорида на содержание кортизола в крови животных с комбинированной моделью сахарного диабета и хронического стресса. Эксперимент выполнен на взрослых крысах-самцах. Сахарный диабет I типа моделировали аллоксана моногидратом (150 мг/кг подкожно однократно), хронический иммобилизационный стресс - помещением животных в тесные пеналы на 16 суток ежедневно в течение 15 дней, начиная с 11 дня после введения аллоксана. Установлено, что концентрация кортизола в плазме крови животных группы контрольной патологии значительно возрастает относительно интактного контроля - в среднем с 77,51 нг/мл до 421,65 нг/мл, то есть в 5,4 раза (р<0,001). Это свидетельствует о напряженности обусловленных кортикостероидами механизмов течения стресс-реакции на фоне модельного сахарного диабета. С учетом контринсулярных свойств кортикостероидов такой эффект длительной иммобилизации на фоне сахарного диабета следует считать особенно неблагоприятным. Диакамфа гидрохлорид (25 мг/кг внутрибрюшинно ежедневно) не только уменьшал гликемию, но и достоверно снижал содержание кортизола в крови в среднем до 172,0 нг/ мл ( $<<0,001$ по сравнению с показателем группы контрольной патологии). Препарат сравнения классический актопротектор бемитил (50 мг/кг внутрибрюшинно ежедневно) статистически значимо уступал диакам$\oint а$ гидрохлориду (р<0,001), уменьшая концентрацию кортизола в среднем лишь до 253,35 нг/мл. Результать свидетельствуют о стресспротекторных свойствах диакамфа гидрохлорида в условиях сахарного диабета и обосновывают перспективность его дальнейшего изучения как потенциального адаптогенного и стресспротекторного средства. Механизм действия диакамфа гидрохлорида связан с его влиянием на эндокринные механизмы стресс-реакции.
\end{abstract}

